\title{
Effect of Sandy Soil Amendment with Filter Mud Cake on Growth and Some EcoPhysiological Parameters of Daucus carota and Beta vulgaris Plants
}

\author{
Noha A. El-Tayeh ${ }^{1}$, Fawzy M. Salama ${ }^{2 *}$, Naglaa Loutfy ${ }^{1}$, Mona F. Abou Alhamd ${ }^{1}$ \\ ${ }^{1}$ Botany Department, Faculty of Science (Qena), South Valley University, Egypt \\ ${ }^{2}$ Botany Department, Faculty of Science (Assuit), Assuit University, Egypt
}

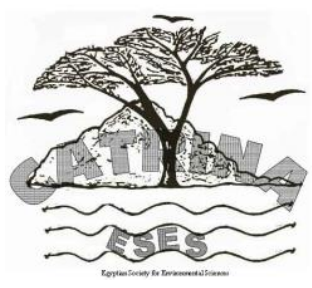

\begin{abstract}
Sand culture technique was employed to investigate the effect of filter mud cake (FMC) from Qus sugarcane factory as fertilizer on water content, dry matter, chlorophylls content and some carbon and nitrogen metabolites in carrot (Daucus carota) and beet (Beta vulgaris) plants. The investigations were carried out under natural conditions using the FMC of Qus sugarcane factory at Qena governorate. The FMC was mixed with sand soil at three levels: $10 \%, 30 \%$ and $50 \%$. The sand soil was used without FMC as control. Results revealed that the amendment of soil with FMC slightly reduced $\mathrm{pH}$ of soil and increased electric conductivity (EC), organic matter (O.M), total nitrogen and organic carbon (O.C) with increasing the FMC level. Dry mass and water content of both tested plants increased significantly by FMC treatment as comparing with control plants. The investigated plants grown on soil amended with FMC levels showed highly significant increase in both chlorophylls content $\mathrm{a}$ and $\mathrm{b}$ than in control plants in both experimental plants. Whereas chlorophyll $\mathrm{a} / \mathrm{b}$ ratio and proline content was decreased significantly. Results indicated also that the soluble sugars, proteins and total amino acids were increased significantly by FMC application in both experimental plants comparing with those grown in unlamented soil. It can be concluded that application of FMC as fertilizer improved the physico-chemical properties of the reclaimed soil to be more suitable for cultivation.
\end{abstract}

Keywords: Chlorophylls, Soluble sugars, Sugarcane, Filter mud cake, Proteins

\section{INTRODUCTION}

Press mud (PM) also known as filter cake (FC) or filter mud (FM) is organic effluents from sugar factories which are used to supply a nutrient rich, high-quality organic manure. Press mud or filter cake, a waste byproduct from sugar factories, is a delicate, spongy, amorphous and dark brown to brown stuff which controls sugar, fiber, coagulated colloids, including cane wax, albuminoids, inorganic salts and dirt particles (Ghulam et al., 2010). It also includes plant growth regulators, auxins, enzymes, vitamins and hormones resulting in maintaining the tilth, fertility, and productivity of agricultural soils (Solaimalai et al., 2001). They also protect the soils from wind and water erosion, thus preventing nutrient losses through runoff and leaching. Press mud or filter cake is one of the important organic wastes capable of providing sufficient amount of plant nutrients to the stain, due to its favorable effects on soil texture, structure, organic matter contents, the water holding capacity and aeration of soil (Ghulam et al., 2010). The fruits of various crops showed significant increases with FMC applications (Rangaraj et al., 2007; Elsayed et al., 2008; Muhammad and Khattak, 2009) that were imputed to the improvement in soil physical, chemical and biological conditions (Barry et al., 2001).

Sandy soils are very poor in their organic matter contents as well as their primitive fertility. On the other hand, organic materials such as crop residues, farmyard manure, industrial wastes (filter mud), etc., are available in abundance and reach tremendous amounts every day. Organic matter is a key component of the soil because it carries out many functions in agro-ecosystem. Organic manure is commonly applied to the soil to hence improve their physical, chemical and biological Pro- perties of many soils (Jimenez et al., 2002; Nardi et al., 2004; Weil and Magdoff, 2004; Celik, et al., 2004).

Fliessbach et al. (2000) suggested that, organic manure application increased the transfer elements between the solid phase and soil solution in addition to higher microbial activity. They also, reported that organic soil management improved the soil structure by increasing soil aggregate, thus, reducing the risk of soil erosion and promoted the development of the soil condition for plant.

In Egypt, a frightful mass of filter mud as byproducts obtained from the clarification of cane juice in sugar industries. These waste residues present a problem for disposal; thus, it was through useful to use residues as an organic source. Sugar can filter mud contain a considerable quantity of plant nutrients, mainly nitrogen (Arafat, 1994). Sugar can filter mud is a source of available $\mathrm{N}$ when applied to the soil and its application can scale down the quantity of fertilizer nitrogen required for optimum crop yield and play a part in lessening the pollution result of excessive $\mathrm{N}$ mineral fertilizer in soil (Arafat et al., 1997; Yassen et al., 2002). Carrot and sugar beet in Egypt are among most popular root vegetables. Carrot is one of the most important vegetables in the world; its bioactive constituents may be beneficial to a huge number of consumers. It is rich in pro-healthy antioxidants, both of lipophilic (carotenoids) and hydrophilic (phenolic compounds) characters (Sharma et al., 2012; Leja et al., 2013). Carrots are a serious source of sugars and minerals like $\mathrm{Ca}, \mathrm{P}, \mathrm{Fe}$ and $\mathrm{Mg}$ (Sharma et al., 2012). This root vegetable contains valuable phytochemicals. The presence of phytochemicals, in addition to vitamins and provitamins, in fruits and vegetables has been recently considered of crucial nutritional importance in 
the prevention of chronic diseases, such as malignant neoplastic disease, cardiovascular disease, and diabetes (Nambia et al., 2010; Jamuna et al., 2011). Red beet has been cultivated already in ancient Egypt. The taproot contains vitamins A, B1, B2, B3, B4, B5, B6, B12, C, anthocyanins and $\mathrm{Fe}, \mathrm{Ca}, \mathrm{Mg}, \mathrm{K}, \mathrm{Mn}, \mathrm{Cu} \mathrm{Cl}, \mathrm{F}, \mathrm{Zn} \mathrm{B}, \mathrm{Li}$ $\mathrm{Mo}, \mathrm{Co}, \mathrm{Rb}$ and $\mathrm{Cs}$. The important constituent of taproot is betaine (trimethylglicine), which has medical application. The leaves also contain folic acid and carotenoids. The present study was therefore carried away to evaluate different doses of press mud used as organic fertilizer and its effect on growth, chlorophyll content, water content, carbohydrates, protein, total free amino acids and proline of carrot and beet plants.

\section{MATERIALS AND METHODS}

\section{Plant materials and growth conditions}

Three pot experiments were carried out to study the effects of applications of organic amendments on sandy soil. Applied organic amendments; Filter mud cake (FMC) was obtained from Qus sugarcane factory, Qena governorate, Egypt. The pot experiments were arranged in a completely randomized design using plastic pots of $35 \mathrm{~cm}$ in diameter and $40 \mathrm{~cm}$ in height and; each one was filled with $6 \mathrm{~kg}$ of the investigated sand soil. Experiments were conducted in the screen house and experimental farm, Faculty of Science, South Valley University, Egypt in the summer season of 2016, to evaluate the effect of sandy soil amendment with filter mud cake on the plant growth and some ecophysiological parameters of carrot (Daucus carota) and beet (Beta ulgaris) plants. Three different substrate treatments were set up. Pre composted filter mud cake (FMC) was used at levels 10\%, 30\% and 50\%.

FMC $\mathrm{pH}$ was measured in a 1:1 ratio of FMC to water suspension using Beckman $\mathrm{pH}$ meter as it was reported by McLean (1982). Organic matter and Organic carbon was determined in the soil + FMC samples by the dichromate oxidation method according to Walkley and Black (1934). Total N was determined using the microkjeldahl method as described by (Jackson, 1973). Six kg of the sand soil/pot were thoroughly mixed with each investigated treatments and then 5 seeds of carrot and beet plants were sown in each pot. Pots were directly irrigated. The control treatment was set up without applying any addition and each treatment was replicated three times. Soil moisture content in all pots was kept at field capacity during the experiment. Hoagland's solution (Hoagland and Arnon, 1950) was added partially at five days intervals.

The chemical analysis of the filter mud cake (FMC) applied in the previous treatments are shown in table (1). At the end of the experimental period (10 weeks) fresh and dry weights of shoots and roots of both experimental plants were determined. To determine the dry weight, the freshly harvested organs (shoots and roots) were dried in an aerated oven at $80^{\circ} \mathrm{C}$. Successive weighing was carried out until the constant dry weight of each sample reached. Chlorophyll $a$ and $b$ were determined spectrophotometrically according to Metzner et al. (1965). The results have been presented as the average of four observations over three replications for each treatment. The water-soluble sugars were quantified by the anthrone sulfuric acid method (Fales, 1951). Soluble proteins were determined according to Lowry et al. (1951). Total Free amino acids were determined according to (Yemm and Cocking, 1955), using Lleucine as standard. Proline was determined by sulfosalicylic acid method described by Bates et al. (1973). The content of each metabolite of the experimental plants were expressed as $\mathrm{mg} / \mathrm{g}$ dry weight.

\section{Statistical analysis}

Data were statistically analyzed using SPSS version 20 software. Analysis of variance (ANOVA) was carried using a general one-way model, and Duncan's test was used for comparison between means.

\section{RESULTS}

\section{Soil properties}

The results of the chemical characteristics of the soil samples presented that electrical conductivity, organic matter, total nitrogen and organic carbon showed significant increase between the FMC levels $(10 \%, 30 \%$ and $50 \%$ ) and soil control. Moreover, the FMC levels had reduction in $\mathrm{pH}$ as compared with control (Table 1). The values of electrical conductivity in soil sample at $10 \%$ FMC was $0.55 \mathrm{~ms} / \mathrm{cm}^{2}$, Furthermore, at $30 \%$ FMC was $1.64 \mathrm{~ms} / \mathrm{cm}^{2}$ while at $50 \%$ FMC was $2.73 \mathrm{~ms} / \mathrm{cm}^{2}$ against soil control which was $5.1 \mathrm{~ms} / \mathrm{cm}^{2}$.The percentage of organic matter was $6.19 \%, 6.51 \%$, $19.44 \%$ and $32.53 \%$ at control, $10 \%, 30 \%$ and $50 \%$ FMC respectively. The percentage of total nitrogen at $10 \%$ FMC was $0.24 \%$, Moreover, at $30 \%$ FMC was $0.69 \%$, whereas at $50 \%$ FMC was $1.13 \%$ against soil control which was $0.22 \%$. The percentage of organic carbon was $3.37 \%, 3.37 \%, 11.16 \%$ and $18.95 \%$ at control, $10 \%, 30 \%$ and $50 \%$ FMC respectively.

Data in table (1) indicated that the soil $\mathrm{pH}$ decreased by increasing level of FMC soil compared with control. Since $\mathrm{pH}$ values was 6.8 at control, 6.77 at $10 \%$ FMC, 6.5 at $30 \%$ FMC and 6.33 at $50 \%$ FMC.

Table (1): EC (expressed as $\left.\mathrm{mS} \mathrm{Cm}^{-2}\right)$, pH values and organic matter (O.M) \%, total nitrogen, organic carbon (O.C\%) of sand and different filter mud cake (FMC) levels, Data are means \pm SE (standard error), $n=3$. Different superscript letters are significantly different at $\mathrm{P}<0.05$ according to Duncan test, $*$ is significant $(\mathrm{P}<0.05)$ and $* *$ is highly significant $(\mathrm{P}<0.01)$.

\begin{tabular}{|c|c|c|c|c|c|}
\hline \multirow{2}{*}{ Parameter } & \multirow{2}{*}{ Control (Sand) } & \multicolumn{3}{|c|}{ Filter mud cake(FMC) levels } & \multirow{2}{*}{ F- value } \\
\hline & & $10 \%$ & $30 \%$ & $50 \%$ & \\
\hline $\mathrm{EC}\left(\mathrm{mS} \mathrm{cm}^{-2}\right)$ & $0.51^{\mathrm{a}} \pm 0.01$ & $0.55^{\mathrm{a}} \pm 0.03$ & $1.64^{b} \pm 0.03$ & $2.73^{\mathrm{c}} \pm 0.06$ & $877.84^{* *}$ \\
\hline O.M \% & $6.13^{\mathrm{a}} \pm 1.37$ & $6.51^{\mathrm{a}} \pm 0.01$ & $19.44^{\mathrm{b}} \pm 0.21$ & $32.53^{\mathrm{c}} \pm 0.27$ & $4664.91^{* *}$ \\
\hline pH & $6.8^{\mathrm{b}} \pm 0.06$ & $6.77^{\mathrm{b}} \pm 0.09$ & $6.5^{\mathrm{a}} \pm 0.06$ & $6.33^{\mathrm{a}} \pm 0.09$ & $8.93 * *$ \\
\hline Total nitrogen \% & $0.22^{\mathrm{a}} \pm 0.01$ & $0.24^{\mathrm{a}} \pm 0.00$ & $0.69^{\mathrm{b}} \pm 0.00$ & $1.13^{\mathrm{c}} \pm 0.03$ & $784.68^{* *}$ \\
\hline O.C \% & $3.37^{\mathrm{a}} \pm 0.09$ & $3.37^{\mathrm{b}} \pm 0.08$ & $11.16^{\mathrm{c}} \pm 0.33$ & $18.95^{\mathrm{d}} \pm 0.04$ & $7261.19^{* * *}$ \\
\hline
\end{tabular}




\section{El-Tayeh et al.}

\section{Growth parameters}

Results of water content and dry mass of shoots and roots of carrots and sugar beet plants are shown in figures (1 and 2). It is clear that amendment of sandy soil with different FMC caused a significant increase in water content of shoots and roots of the studied plants as compared with control ones in both plants. The FMC significantly increased water content in roots of carrot which was $32.55 \%, 24.99 \%$ and $24.26 \%$ as against $10 \%$, $30 \%$ and $50 \%$ FMC levels compared by control (Fig. 1).While the increase in water content in shoots of carrot was about $40 \%$ higher than the control at all FMC levels. On the other hand, the increase in roots of sugar beet plants was $26.88 \%, 17.80 \%$ and $18.31 \%$ as against $10 \%, 30 \%$ and $50 \%$ FMC levels, respectively as compared by the control and in shoots was 5.18\%, 6.32\% and 8.19\% (Fig. 2). From the present results one can noted that the increase in water content in carrot was higher than in sugar beet.

Additionally, the increase in water content in roots of sugar beet was higher than in shoots on contrast carrot since the increase in shoot was higher than root.

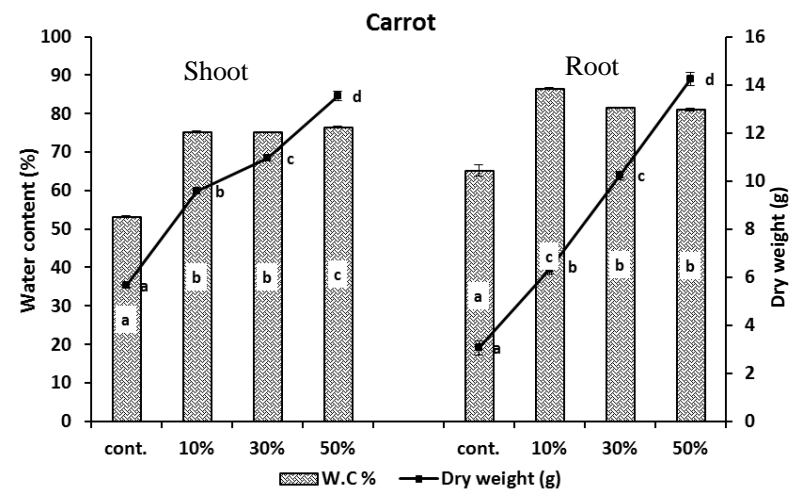

Figure (1): Water content (\%) and dry mass (expressed as g individual-1) of shoots and roots of carrots plants grown on sand "control" and different levels of FMC. Data are means \pm SE (standard error), $n=3$. In each panel, means of dry mass and water content of shoots or roots with different letters are significantly different at $\mathrm{p}>0.05$ according to Waller-Duncan test

sugar beet

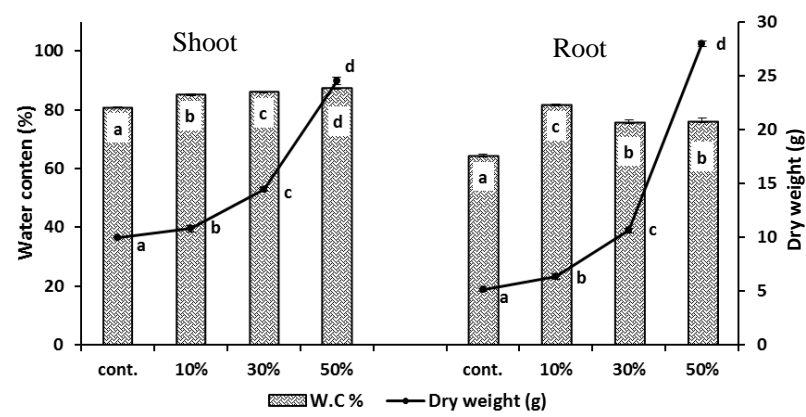

Figure (2): Water content (\%) and dry mass (expressed as g individual-1) of shoots and roots of beet plants grown on sand "control" and different levels of FMC. Data are means $\pm \mathrm{SE}$ (standard error), $\mathrm{n}=3$. In each panel, means of dry mass and water content of shoots or roots with different letters are significantly different at $p>0.05$ according to Waller-Duncan test.
Dry mass of two tested plants increased significantly by increasing FMC levels as compared with control plants. Dry mass reached a maximum value (1.4- fold higher than control) at 50\% FMC in shoots of carrot and sugar beet and remained significantly higher than control at $10 \%$ and 30\% FMC (Figures 1 and 2). On the other hand, the increase in dry mass in roots was about 3.5 and 4.5-fold higher than control in carrot and sugar beet, respectively at 50\% FMC level. From prior detected that the increase in dry mass in roots of sugar beet was higher than in roots of carrots. Generally, treatments of the sandy soils with FMC resulted in significantly higher efficiency for plant characteristics and increase in yields of both tested plants especially sugar beet.

It has been confirmed that treatment of carrots and sugar beet plants by different filter mud cake (FMC) levels showed different degrees in chlorophylls content (Figures 3 and 4). The differences have been observed in Chl.a and $\mathrm{b}$ contents and Chl.a/Chl.b ratio between untreated plants (control) and FMC treated plants. The maximum increase in Chl.a and Chl.b (91 and 240\% in sugar beet and 136 and $346 \%$ in carrot) respectively was recorded in $50 \%$ FMC compared to control. The FMC significantly decreased Chl.a/Chl.b ratio in carrot and sugar beet plants as compared with control.

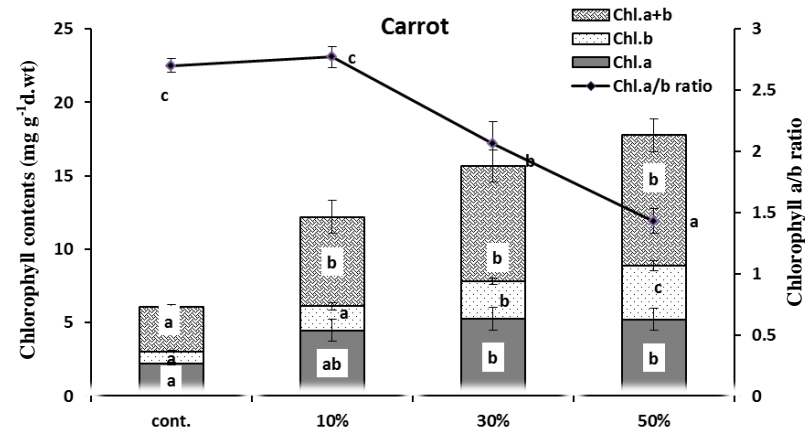

Figure (3): Contents of chlorophyll (Chl.) a and b (mg g ${ }^{-1}$ f.wt) and Chl.a/Chl.b ratio in leaves of carrot plants grown on sand "control" and different levels of FMC. Data are means $\pm \mathrm{SE}, \mathrm{n}=3$. In each panel, means of Chl.a, Chl.b or Chl.a/b ratio with different letters are significantly different at $p>$ 0.05 according to Waller-Duncan test.

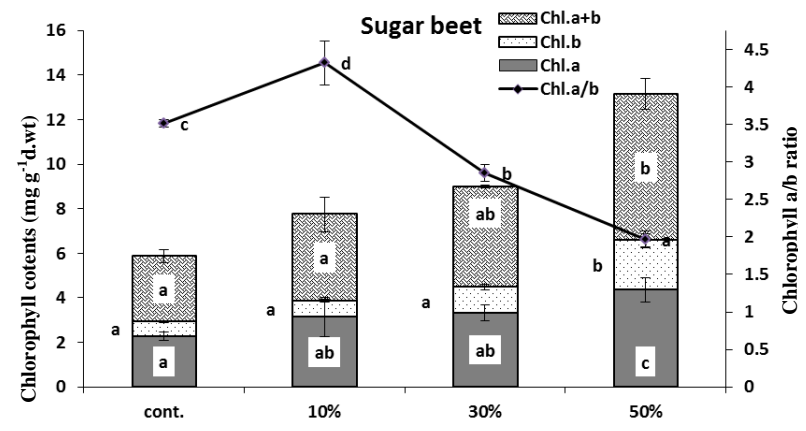

Figure (4): Contents of chlorophyll (Chl.) a and b (mg g $\left.\mathrm{g}^{-1} \mathrm{f} . \mathrm{wt}\right)$ and Chl.a/Chl.b ratio in leaves of beet plants grown on sand "control" and different levels of FMC. Data are means \pm $\mathrm{SE}, \mathrm{n}=3$. In each panel, means of Chl.a, Chl.b or Chl.a/b ratio with different letters are significantly different at $\mathrm{p}>$ 0.05 according to Waller-Duncan test. 


\section{Biochemical characteristics}

Data presented in figures (5 and 6) showed that there was a significant increase in soluble sugars, total amino acids and proteins under FMC treatment compared to control.

The soluble sugars (SS) in shoots of carrot was 18.63 , $27.18,29.31$ and $34.79 \mathrm{mg} / \mathrm{g}$ dry weight at $0.0,10 \%$, $30 \%, 50 \%$ FMC, respectively. However, SS in roots of carrot was 39.51, 47.73, 58.81 and $67.47 \mathrm{mg} / \mathrm{g}$ dry weight at $0.0,10 \%, 30 \%, 50 \%$ FMC, respectively. In sugar beet, the soluble sugars content in shoots was $19.45,27.94,32.92$ and $36.0 \mathrm{mg} / \mathrm{g}$ dry weight at 0.0 , $10 \%, 30 \%, 50 \%$ FMC, respectively. While in roots were $48.38,52.3,74.92$ and $88.82 \mathrm{mg} / \mathrm{g}$ dry weight at 0.0 , $10 \%, 30$ and 50\% FMC, respectively.

Total free amine acids in shoots of carrot had values $16.85,20.12,24.42$ and 28.98 against $0.0,10 \%, 30 \%$ and $50 \%$ FMC. While in roots of carrot was 32.96, 37.77, 45.37 and 51.53 (Fig. 5). Moreover, in shoots of sugar beet, values of total free amino acids was 17.08, $22.58,26.67$ and 31.76 against $0.0,10 \%, 30 \%$ and $50 \%$
FMC, and in sugar beet roots were 36.27, 41.02, 48.48 and 55.95 against $0.0,10 \%, 30 \%$ and 50\%, FMC (Fig. $6)$. The increase in soluble protein content of carrot at $10 \%$ FMC was $12.87 \%$ in shoots and $21.87 \%$ in roots higher than control. Furthermore, at $30 \%$ was $30.49 \%$ in shoots and $60.86 \%$ in roots as compared with control (Fig. 5). Whereas at $50 \%$ was $58.02 \%$ in shoots and $66.5 \%$ in roots higher than control. In sugar beet, while the increase in shoots protein was $35.76 \%, 81.67 \%$ and $315.38 \%$ at $10 \%, 30 \%, 50 \%$ FMC as compared with control, respectively. The increase in roots protein was $10.17 \%, 25.11$ and $38.81 \%$ at $10 \%, 30 \%, 50 \% \mathrm{FMC}$ as compared with control respectively (Fig. 6).

Proline content in contrast to the soluble sugars, total amino acids and proteins showed significantly decrease when treated the two tested plants with FMC. Decrease in proline content in roots of carrot and sugar beet reached about $70 \%$ lesser than content at the highest level of FMC (50\%). However, in shoots of two tested plants, the decrease reached about $60 \%$ lesser than content at the highest level (50\%) of FMC.

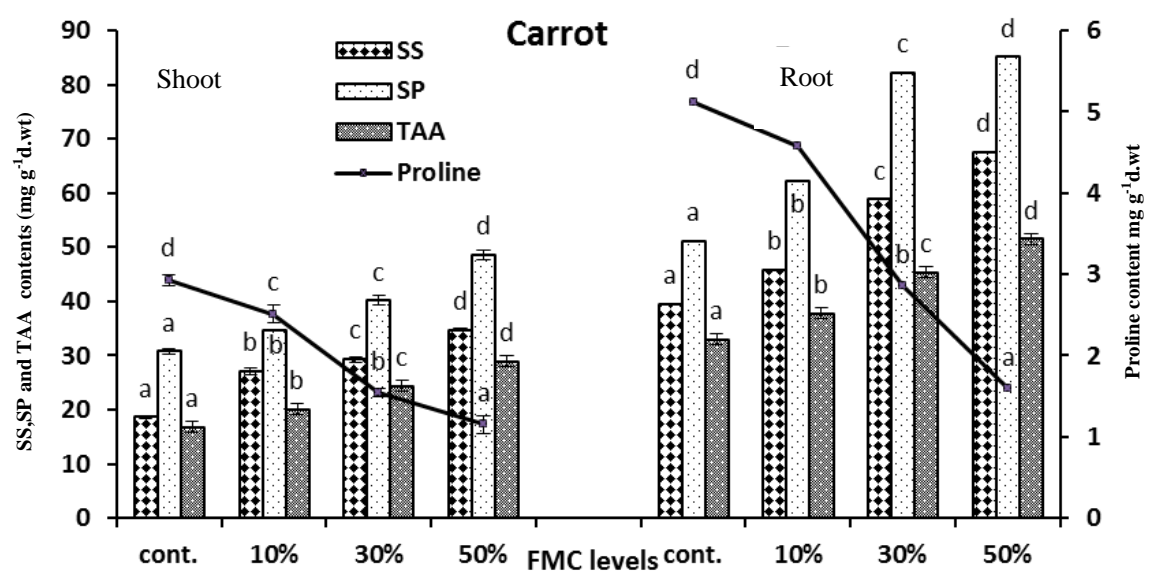

Figure (5): Concentrations of soluble proteins (SP), total free amino acids (TAA), soluble sugars (SS) and proline (expressed as mg $\mathrm{g}^{-1} \mathrm{~d}$.wt) in shoots and roots of carrot plants grown on sand "control" and different levels of FMC. Data are means $\pm \mathrm{SE}, \mathrm{n}=3$. In each panel, means of SP, TAA and SS in shoots or roots with different letters are significantly different at $\mathrm{p}<0.05$ according to Waller-Duncan test.

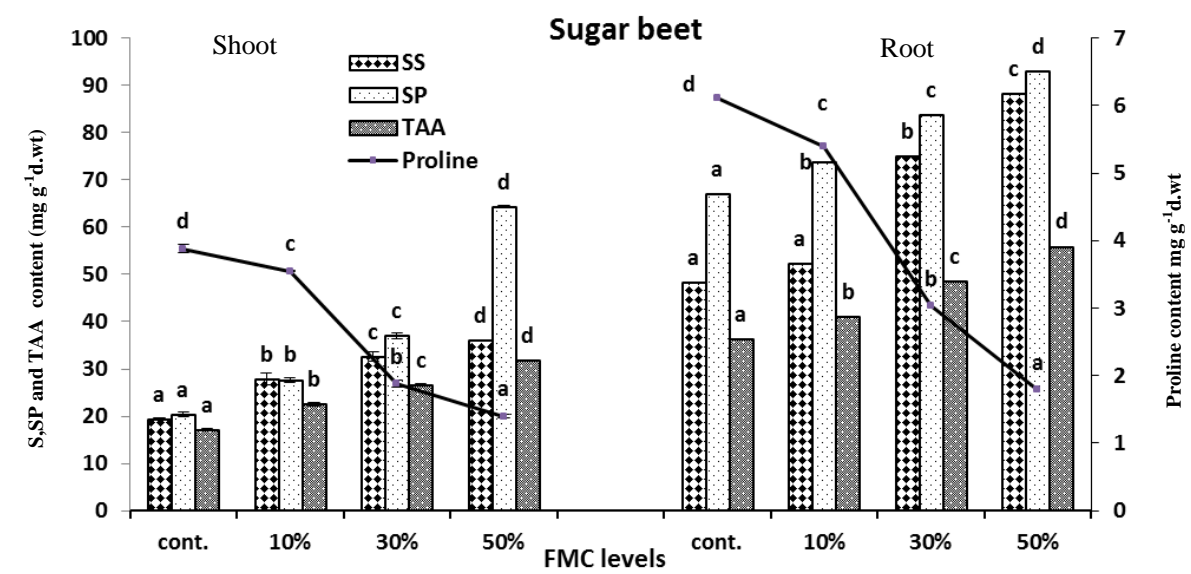

Figure (6): Concentrations of soluble proteins (SP), total free amino acids (TAA), soluble sugars (SS) and proline (expressed as mg g-1d.wt) in shoots and roots of sugar beet plants grown on sand "control" and different levels of FMC. Data are means $\pm \mathrm{SE}, \mathrm{n}=3$. In each panel, means of SP, TAA and SS in shoots or roots with different letters are significantly different at $\mathrm{p}<0.05$ according to Waller-Duncan test. 


\section{El-Tayeh et al.}

\section{DISCUSSION}

Filter cake has been used as a bio-fertilizer and it had a positive effect on plant growth and soil biochemical and physical properties (Wongkoon et al., 2014). Moreover, it contains plant growth regulators, auxins, enzymes, vitamins and hormones (Solaimalai et al., 2001). The present results showed that soil $\mathrm{pH}$ decreased from 6.8 (control) to 6.33 at 50\% FMC. While EC, organic matter, total nitrogen and organic carbon were increased proportionally with the level of sand-FMC mixture. These results are in agreement with the findings of Ghulam et al. (2010) who described the application of press mud decreased the soil $\mathrm{pH}$ while increased the electrical conductivity (EC), organic matter and total nitrogen of the soil.

In the present study, effect of $10 \%, 30 \%$ and $50 \% \mathrm{FMC}$ were tested for their efficiency on plant growth of carrot and sugar beet plants and the results clearly showed that FMC levels significantly improved the plant growth and related plant parameters. Our results showed a significant increase in water content and dry mass in FMC treated plants compared to control plants. These results are according to the findings of Yassen et al., 2010 and Hassan et al., 2017 they found that Filter mud cake and some natural materials usage improved growth and yield of Capsicum frutescens L. plants and wheat plants, respectively. Furthermore, Santos et al. (2010) and Rossetto et al. (2008) described that filter mud cake (FMC) increased sugarcane yield and supported that the organic matters release $\mathrm{P}$ and $\mathrm{Ca}$ and others nutrients increasing nutrient uptake.

Photosynthetic pigment is one of the acute factors determining photosynthetic efficiency and plant growth (Shao et al., 2014). Data of the present investigation reviled that a significant increase in Chl.a and $b$ in tested plants subjected to FMC treatments. This increase in chlorophylls content might be due to increase in nutrient. Chl.a and b in tested plants subjected to FMC treatments. This increase in chlorophylls content might cause by increase in minerals which result of application of FMC. Since the biosynthesis of photosynthetic pigments may be due to the suitable supply of metal ions in the growth medium (Jaleel et al., 2009). Kumar and Chopra (2016) reported that Filter mud cake (FMC) had a significant amount of macro-nutrients and traces of micro-nutrients.

Filter mud cake (FMC) contains micro-nutrients which in low levels are useful for the growth and metabolism of plants, on the other hand they are toxic when are in excess than their required levels. Some of micronutrients are heavy metals and produce harmful effects on plants (Jemai et al. 2013). Data of soluble sugars in shoots and roots of both experimental plants showed an increase in soluble sugars cotents. Some researchs indicates that the salinity water logging, frost and heavy metal increase soluble sugars (Van and Clijsters, 1990; Sthanadar et al., 2014). Accumulation of soluble sugars helps regulate osmotic stress in plant cells and leads to preservation of biological molecules and membranes (Irannejad and Shahbazian, 2004). The plant with the increase in soluble sugar in addition to maintaining the osmotic potential in stress conditions, will be able to store their carbohydrate metabolism of the cell is kept at an optimum level (Gibson, 2005).

In the current results, FMC treatments significantly increased soluble proteins. Gao et al. (2008) found that soluble proteins content of Jatropha curcas seedlings was increased by copper stress. Total free amino acid was increased by increasing FMC concentration in both shoots and shoots of carrot and sugar beet. In agreement with our results, several studies have been indicated that free amino acids content increases in plant tissues upon heavy metal exposure (Liao et al., 2000; Mazen, 2004; Al-Hakimi and Hamada, 2011). Amino acids are regarded to play a significant role in metal chelation, by which heavy metal detoxification and tolerance in plants take place (Hall, 2002). Hence, it might be suggested that, the positive response of soluble sugar, soluble proteins and total free amino acids under heavy metal stress in the current work might be a detoxification response of carrot and sugar beet to heavy metal, to tolerate the presence of excess heavy metal.

Conversely, proline decreased with increasing FMC levels in both of the experimental plants. Such decrease in proline may be an adaptive response to FMC treatment. This finding agrees with Yassen et al. (2010).

The present study exhibited that FMC can be effective in increasing carrot and sugar beet growth. This due to effect of FMC on soil properties, since FMC increased organic matter, total nitrogen and organic carbon. This indicates that, due to the increase in filter mud amended soil enhanced microbial activates, which increase nutrient availability and their uptake and increasing root distribution. These results are in a good agreement that obtained by Yaduvanshi and Sharma (2008).

\section{REFERENCES}

AL-HAKIMI, A.M., AND A.M. HAMADA. 2011. Ascorbic Acid, Thiamine or Salicylic Acid Induced Changes in Some Physiological Parameters in Wheat Grown Under Copper Stress. Plant Prot. Sci. 47: 92-108.

ARAFAT, S.M. 1994. Evaluations of Sugarcane Filter Mud on Improving Soil Characteristics and Watermelon Yield. Egypt J Appl Sci 9 (9):287-295.

ARAFAT, S.M., H. EL-AILA, AND A. ALGLI. 1997. Utilization of Sugar Cane Filter Mud to Minimize Nitrogen Fertilizers for Sorghum Growth. J Agric Sci Mansoura Univ 22(4): 1267 -1276.

BARRY, G.A., G.E. RAYMENT, A.J. JEFFERY, AND A.M. PRICE. 2001. Changes in Cane Soil Properties from Application of Sugar Mill By-Products. p. 185199. In: Proceeding Conference of the Australian Society of Sugarcane Technology Mackay Queensland Australia.

BATES, L.S., R.P. WALDREN, AND I.D. TEARE. 1973. Rapid Determination of Free Proline for Water Stress Studies. Short communication. Plant and Soil. 39: 205-20.

CELIK, I., I. ORTAS, AND S. KILIC. 2004. Effects of Compost, Mycorrhiza, Manure and Fertilizer on 
some Physical Properties of a Chromoxerert Soil. Soil Till. Res 78: 59-67.

ELSAYED, M.T., M.H. BABIKER, M.E. ABDELMALIK, O.N. MUKHTAR, AND D. MONTANGE. 2008. Impact of Filter Mud Application on The Germin-ation of Sugarcane and Small Seeded Plants and on Soil and Sugarcane Nitrogen Contents. Biores Technol. 99: 181-186.

FALES, F.W. 1951. The Assimilation and Degradation of Carbohydrate by Yeast cells. J Biol Chem 193: 113-124.

FLIESSBACH, A.P., D. MADER, D. DUBOIS, AND L. GUNST. 2000. Results from a 21 Years Old Fieldtrial. Organic Farming Enhance Soil Fertility and Biodiviersity Fi B1 Dossier N1, 15, pp19.

GAO, S., R. YAN, M. CAO, W. YANG, S. WANG, AND F. CHEN. 2008. Effect of Copper on Growth, Antio-xidant Enzymes and Phenylalanine AmmoniaLyase Activities in Jatropha curcus L. seedlings. Plant Soil Environ 54(3): 117-122.

GHULAM, S., M.J. KHAN, K. USMAN, AND H. REHMAN. 2010. Impact of Press Mud as Organic Amendment on Physico-Chemical Characteristics of Calcareous Soil. Sarhad J Agric 26(4): 565-570.

GIBSON, S. 2005. Control of Plant Development and Gene Expression by Sugar Signaling. J Plant Biol 8: 93-102.

HALL, J.L. 2002. Cellular Mechanisms for Heavy Metal Detoxification and Tolerance. J Exp Bot 53: $1-11$.

HASSAN, E.A., A.S.A. ABDEL-MOWGOUD, A.E. EL GOHARY, AND A.A. EL SHAZLY. 2017. Filter Mud Cake and some Natural Materials Usage to Improve Growth, Yield and Chemical Constituents of Capsi-cum frutescens L. plants. Middle East J Agric Res 6(4): 1005-1013.

HOAGLAND, D.R., AND D.I. ARNON. 1950. The water Culture Method for Growing Plants without Soil. California Agricultural Experimental Station, Cir: pp. 347-352.

IRANNEJAD, H., AND N. SHAHBAZIAN. 2004. Filed crops tolerance to stress. University of Tehran Press.

JACKSON, M.L. 1973. Soil Chemical Analysis. Prentice-Hall, Inc. Englewood Cliffs, N J New Delhi India.

JALEEL, C.A., K. JAYAKUMAR, Z. CHANG-XING, AND M. IQBAL. 2009. Low Concentration of Cobalt Increases Growth, Biochemical Constituents, Mineral Status and Yield in Zea mays. J Sci Res 1: 128-137

JAMUNA, K.S., C.K. RAMESH, T.R. SRINIVASA, AND K.L. RAGHU. 2011. In vitro antioxidant studies in some common fruits. Inter. J PPS 3: 6063.

JEMAI, I., N. BEN AISSA, T. GALLALI, AND F. CHENINI. 2013. Effects of municipal reclaimed wastewater irrigation on organic and inorganic composition of soil and groundwater in Souhil Wadi area (Nabeul, Tunisia). Hydrol Curr Res 4:160.

JIMENEZ, M.P., A.M. HORRA, L. PRUZZO, AND R.M. PALMA. 2002. Soil Quality: A New Index
Based on Microbiological and Biochemical Parameter, Biology and Fertility of Soils 35 pp. 302306.

KUMAR, V., AND A.K. CHOPRA. 2016. Effect of Sugarcan Pressmud on a Gronomical Characteristics of Hybrid Cultivar of Eggplant (Solanum melongena L.) Under Field Conditions. Int. J Recycl Org Waste Agricult 5: 149-162.

LEJA, M., I. KAMINSKÁ, M. KRAMER, A. MAKSYLEWICZ-KAUL, D. KAMMERER, R. CARLE, AND R. BARANSKI. 2013. The Content of Phenolic Compounds and Radical Scavenging Activity Varies with Carrot Origin and Root Color. Plant Foods Human Nutr 68:163-170.

LIAO, M.T., M.J. HEDLEY, D.J. WOOLLEY, R.R. BROOKS, AND M.A. NICHOLS. 2000. Copper Uptake and Translocation in Chicory (Cichorium intybus L. cv Grasslands Puna) and Tomato (Lycopersicon esculentum Mill. CvRondy) plants grown in NFT system. II. The Role of Nicotianamine and Histidine in Xylem Sap Copper Transport. Plant Soil 223: 243-252.

LOWERY, O.H., N.J. RASEBROUGH, A.L. FARR, AND R.J. RANDALL. 1951. Protein Measurement with The Folin Phenol Reagent. J Biol Chem 193:291-297.

MAZEN, A.M.A. 2004. Accumulation of Four Metals in Tissues of Corchorus Olitorius and Possible Mechanisms of Their Tolerance. Biol Plant 48: 267272.

MCLEAN, E.O.P.H. 1982. Soil, Lime Requirement in: A. L. Page, R.H. Miller And D. R. Keeney (EDS.) 199-224. Methods of Soil Analysis. Am. Soc. Agronm. and Soil. Sci.Soc. Am. Madison, WI, USA.

METZNER, H., H. RAU, AND H. SENGER. 1965. Untersuchangen zur Synchronisierbarkeit einzelner pigmentmangle - mutanten von Chlorella. Planta 65: 186-194.

MUHAMMAD, D., AND R.A. KHATTAK. 2009. Growth and Nutrient Concentrations of Maize in Press Mud Treated saline-sodic soils. Soil Environ 28(2): 145-155.

NAMBIA, V.S., M. DANIEL, AND P. GUIN. 2010. Characterization of Polyphenols from Coriander Leaves (coriandrum sativum), Red Amaranthus ( $a$. paniculatus) and Green Amaranthus (a. frumentaceus) Using Paper Chromatography: and Their Health Implications. J Herbal Med Toxic 4: 173177.

NARDI, S., F. MORARI, A. BERTI, M. TOSONI, AND L. GIARDINI. 2004. Soil Organic Matter Properties after 40 Years of Different Use of Organic and Minerals Fertilizers. Eur J Agron 21: 357-367.

RANGARAJ, T., E.M. SOMASUNDARAM, M. AMANULLAH, V. THIRUMURUGAN, S. RAMESH, AND V. RAVI. 2007. Effect of AgroIndustrial Wastes on Soil Properties and Yield of Irrigated Finger Miller (Eleusine Coracana L. Gaertn) In Coastal Soil. Res J Agric Biol Sci 3 (3): 153-156.

ROSSETTO, R, F.L.F. DIAS, AND A.C. VITTI. 2008. 


\section{El-Tayeh et al.}

Nutritional Problems in Soils from The New Sugarcane Frontiers. Idea News 8: 78-90.

SANTOS, D.H., C.S. TIRITAN, J.S.S. FOLONI, AND L.B. FABRIS. 2010. Productivity of Sugarcane under Application of Mud Cake Enriched with Soluble Phosphate. Pesq Agropec Trop 40:454-461.

SHAO, Q.S., H.Z. WANG, H.P. GUO, A.C. ZHOU, Y.Q. HUANG, AND Y.L. SUN. 2014. Effects of Shade Treatments on Photosynthetic Characteristics, Chloroplast Ultrastructure, and Physiology of Anoectochilus roxburghii. PLOS ONE 9:e85996. doi: 10.1371/journal.pone.0085996.

SHARMA, K.D., S. KARKI, N.S. THAKUR, AND S. ATTRI. 2012. Chemical Composition, Functional Properties and Processing of Carrot. J Food Sci Techn 49: 22- 32.

SOLAIMALAI, A., M. BASKAR, P.T. RAMESH, AND N. RAVISANKAR. 2001. Utilisation of Press Mud as Soil Amendment and Organic Manure - A review. Agric Rev 22(1): 25 - 32.

STHANADAR, I.I., A.A. STHANADA, AND M. YOUSAF. 2014. Bioaccumulation Profile of Heavy Metals in The Gills Tissue of Wallago attu (Mulley) from Kalpani River Mardan, Khyber Pakhtunkhwa Pakistan. Inter J Biosci 3: 165-174.

VAN, A.F., AND H. CLIJSTERS. 1990. Effects of Metals on Enzyme Activity in Plants. J. Plant Cell Environ 13 (3):195-206.

WALKLEY, A., AND I.A. BLACK. 1934. An examination of the Detjareff method for determining soil organic matter and a proposed modification of the chromic acid titration method. Soil Sci. 37: 2938.

WEIL, R.R., F. MAGDOFF. 2004. Significance of Soil Organic Matter to Soil Quality and Health. In: F. Magdoff and R.R. Weil, Editors, Soil Organic Matter in Sustainable Agriculture, CRCPress, Boca Raton FL USA pp. 1-43.

WONGKOON, T., S. BOONLUE, AND N. RIDDECH. 2014. Effect of compost made from filter cake and distillery slop on sugarcane growth. KKU Res J 19: 250-255.

YADUVANSHI, N.P.S., AND D.R. SHARMA. 2008. Tillage and Residual Organic Manures/Chemical Amend-ment Effects on Soil Organic Matter and Yield of Wheat Under Sodic Water Irrigation. Soil Tillage Res 98: 11-16.

YASSEN, A.A., S.M. ARAFAT, AND M.Z. SAHAR. 2002. Maximizing Use of Vinasse and Filter Mud as by-Products of Sugar Can on Wheat Production. J Agric Sci Mansoura Univ 27(11): 7865-7873.

YASSEN, A.A., S.M. KHALED, AND S.M. ZAGHLOUL. 2010. Response of Wheat to Different Rates and Ratios of Organic Residues on Yield and Chemical Composition Under Two Types of Soil. J Amer Sci 6(12): 858-864

YEMM, E.W., AND E.C. COCKING. 1955. The Determination of Amino-Acids with Ninhydrin. The Analyst 80: 209-213. 
تأثير تسميد التربة الرملية بطينة المرشحات على النمو وبعض الخصائص البيوكيميائية لنباتات الجزر وبنجر السكر

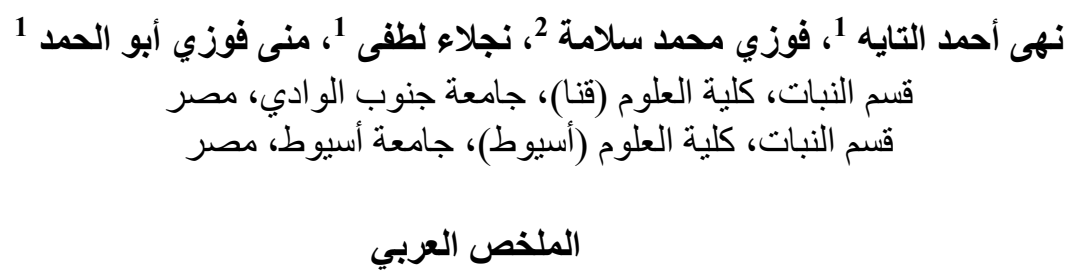

استُخدمت المزارع الرملية في در اسة تأثنير التسمبد بطينة المرشحات (FMC) على المحتوى المائي والمادة الجافة ومحتوى الكلوروفيل وبعض النواتج الايضية الكربونية و النيتروجينية في نباتات الجزر ( Daucus )

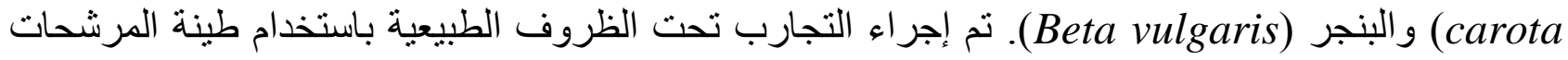
لمصنع قصب السكر بقوص في محافظة قنا. خلطت طينة المرشحات بالتربة الرملية في ثلاثة مستويات: 10٪، 30٪ و 50٪. استخدمت التربة الرملية فقط بدون طينة المرشحات لتكون الكنترول. اظهرت النتائج أن تسميد التربة بطينة المرشحات يؤدي الي خفض الأس الهيدروجيني لمحلول التربة ويزيد من قيم التوصيليه الكهربيه

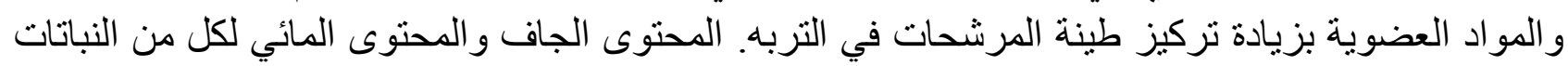

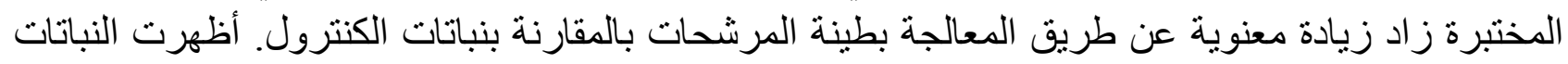

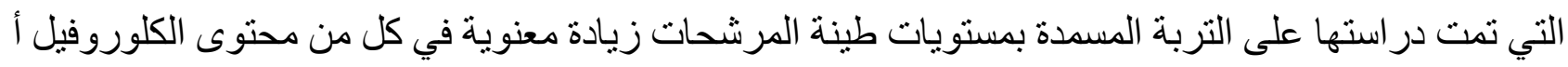
و ب بالمقارنة بنباتات الكنترول. في حين انخفضت نسبة الكلوروفيل أ / ب ومحتوى البرولين بشكل واضح.

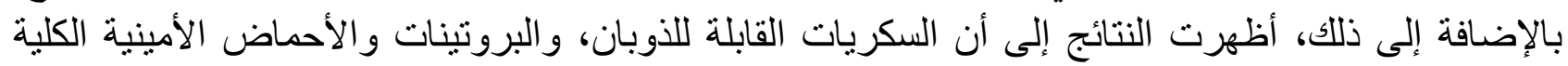

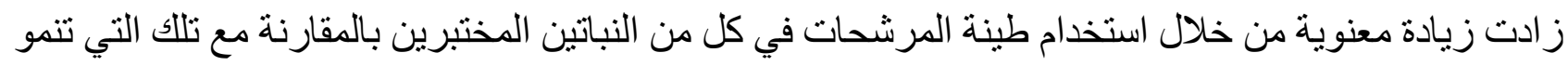
في تربة غير مسمدة. ويمكن الاستنتاج أن استخدام طينة المرشحات كسماد قد حسّن من الخواصنة اصنية الفيزيائية ـ

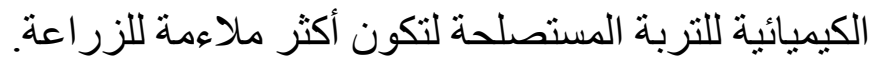

